\title{
Nine Pack
}

National Cancer Institute

\section{Source}

National Cancer Institute. Nine Pack. NCI Thesaurus. Code C78781.

A product containing nine individual units. 